\title{
Effects of Soluble Silicate and Nanosilica Application on Rice Nutrition in an Oxisol
}

\author{
Rita de Cassia FÉLIX ALVAREZ ${ }^{1, *}$, Renato de Mello PRADO ${ }^{2}$, Guilherme FELISBERTO ${ }^{2}$, \\ Angélica Cristina FERNANDES DEUS ${ }^{2}$ and Raimundo Leonardo LIMA DE OLIVEIRA ${ }^{2}$ \\ ${ }^{1}$ Federal University of Mato Grosso do Sul, Chapadão do Sul 79560-000 (Brazil) \\ ${ }^{2}$ University of the State of São Paulo, UNESP, School of Agronomic Sciences, Department of Soils and Fertilizers, Jaboticabal 14884- \\ 900 (Brazil)
}

(Received August 18, 2017; revised July 18, 2018)

\begin{abstract}
Silicon $(\mathrm{Si})$ has been supplied to plants via application of calcium silicate to soil; however, high doses of calcium silicate are required because of its low solubility. Nanoparticles can reduce Si doses and be applied to seeding furrows. This study investigated the effects of liquid Si sources, i.e., highly soluble silicate $\left(115.2 \mathrm{~g} \mathrm{~L}^{-1} \mathrm{Si}\right.$ and $\left.60.5 \mathrm{~g} \mathrm{~L}^{-1} \mathrm{Na}_{2} \mathrm{O}\right)$ and nanosilica $(<200 \mathrm{~nm})$, on $\mathrm{Si}$ uptake by rice plants, plant lignification, plant C:N:P stoichiometry, plant physiology, and grain yield using an Oxisol under greanhouse condistions. The treatments included the application of nanosilica and soluble silicate to seeding furrows at $\mathrm{Si}$ doses of 0,605, 1210, and $2420 \mathrm{~g} \mathrm{ha}^{-1}$. Plant uptake and treatment effects were evaluated by measuring $\mathrm{C}$ and lignin contents, $\mathrm{Si}, \mathrm{N}$, and P accumulation, physiological characteristics, and grain yield of rice. The deposition of silica bodies and amorphous silica in the flag leaves was analyzed using scanning electron microscopy. Application of liquid Si increased Si accumulation in rice by $47.3 \%$ in relation to the control $(0$ $\mathrm{g} \mathrm{ha}^{-1} \mathrm{Si}$ ), regardless of the Si sources used. Nanosilica application increased leaf lignin content by $112.7 \%$ when compared to that in the control. Silicon moderately affected the net C assimilation (increased by $1.83 \%$ ) and transpiration rates (increased by $48.3 \%$ ); however, Si influenced neither plant growth nor grain yield of rice. These results are explained by the lack of biotic or abiotic stress in rice plants during the experiment. To the best of our knowledge, in Brazilian agriculture, this is the first report on the use of nanosilica as a Si fertilizer and its effect on plant nutrition. This study provides evidence that rice plants absorb and accumulate nanoparticles; however, further studies are required to investigate the use of nanoparticles in other plant species.
\end{abstract}

Key Words: C:N:P stoichiometry, grain yield, leaf lignin, net $\mathrm{C}$ assimilation, plant physiology, silicon source

Citation: Félix Alvarez R C, Prado R M, Felisberto G, Fernandes Deus A C, Lima de Oliveira R L. 2018. Effects of soluble silicate and nanosilica application on rice nutrition in an Oxisol. Pedosphere. 28(4): 597-606.

Silicon ( $\mathrm{Si}$ ) is classified as a beneficial or useful element for plant growth (Marschner, 1995; Mendes et al., 2011). The beneficial effects of Si on crops include yield gain, increased resistance to pests and diseases (biotic factors), and the mitigation of metal toxicity, salt stress, and drought stress (abiotic factors), among others (Epstein, 2001). Rice (Oryza sativa L.) accumulates Si (Mengel and Kirkby, 1987; Ma et al., 2001; Mendes et al., 2011), leading to improved crop nutrition and induction of the formation of organosilicon in the leaves, which cooperate to improve crop yield under biotic or abiotic stress. The benefits of Si application to rice may vary. Some studies indicate a lack of response of rice plant to Si (Ramos et al., 2012; Artigiani et al., 2014) because of the absence of stressors. Other reports claim grain yield increase in response to Si application in the presence of stressors (Korndörfer et al., 1999b; Guimarães et al., 2013; Moro et al., 2015). The inc- rease of rice sheath lignification is one of the beneficial effects of Si. Element Si is associated with the lignincarbohydrate complex in leaf epidermal cell walls and increases lignification in these structures, consequently improving resistance to pests and pathogens (biotic factors) (Schurt et al., 2013). The presence of Si in the leaf blades, sheaths, and stems reduces the $\mathrm{C}$ content present in these parts of the plant. Thus, metabolic costs are lowered since $\mathrm{Si}$ compounds are energetically cheaper to form compared with C compounds. Moreover, higher Si supply increases shoot growth of Phragmites australis by altering the C:N:P stoichiometry in plant tissues (Schaller et al., 2012).

The most common $\mathrm{Si}$ source in agriculture is calcium silicate, some of which is derived from industrial or mining waste, such as steel slag. In this case, calcium silicate is likely to be contaminated with phytotoxic heavy metals (Prado et al., 2001). Other Si 
sources include wollastonite, a naturally occurring rock of limited availability, and manufactured sources such as potassium silicate. Relatively high doses of Si (960 $\mathrm{kg} \mathrm{ha}{ }^{-1}$ ) have been used in some rice crop studies (Korndörfer et al., 1999a), since it can be lost (rendered unavailable to plants) due to polymerization reactions after the incorporation into soil. Silicon can be applied in planting furrows in the form of nanoparticles to decrease its doses applied to soil while maintaining efficacy. This method favors plant nutrition because the nanoparticles have a large specific surface area (Nair et al., 2010). Nevertheless, further studies are needed to understand the effect of nanoparticles on plants (Tripathi et al., 2015), as their use in nutrient solutions is limited (Janmohammadi and Sabaghnia, 2015).

Studies on soluble Si sources supplied to rice crops, especially potassium silicate, have focused on foliar applications (Pawar and Hegde, 1978; Hegde and Pawar, 1981). No research has been reported on silicate application to soil, while few studies have addressed the use of $\mathrm{Si}$ nanoparticles in agriculture. The investigation of the use of Si nanoparticles is an important first step to expand Si application to rice crops. Nevertheless, the effect of new $\mathrm{Si}$ sources on rice crops, aiming to meet crop demands, increase the production of basic organic compounds, and boost yield, may be more prominent under biotic and/or abiotic stresses. One hypothesis is that nanosilica will perform better compared with other soluble Si sources, regarding Si uptake by plants, lignin biosynthesis, C:N:P stoichiometry, and grain yield in rice. The objective of this study was to evaluate the effects of highly soluble silicate and nanosilica, applied to rice seeding furrows, on plant $\mathrm{Si}$ uptake, lignin content, $\mathrm{C}: \mathrm{N}: \mathrm{P}$ stoichiometry, physiological attributes, and grain yield of rice.

\section{MATERIALS AND METHODS}

\section{Experimental site and soil}

The experiment was carried out between January and April 2016 under greenhouse conditions at São Paulo State University (UNESP), Jaboticabal, Brazil. The minimum and maximum temperatures and relative humidity during the experimental period were 21 ${ }^{\circ} \mathrm{C}, 37^{\circ} \mathrm{C}$, and $43 \%$, respectively (Fig. 1). Environmental conditions were favorable for rice crop development. The soil was classified as Oxisol (Embrapa, 2013), with a clayey texture $(15.6 \%$ sand, $26.9 \%$ silt, and $57.5 \%$ clay) at 0-20 cm depth. Soil samples were air-dried and sieved through a 2-mm mesh sieve. Random samples were taken to determine chemical properties (Van Raij et al., 2001): pH 6.6 (in $1 \mathrm{~mol} \mathrm{~L}^{-1} \mathrm{CaCl}_{2}$ ), organic ma- tter $6.0 \mathrm{~g} \mathrm{~kg}^{-1}$, P extracted by Mehlich-1 extractant $2.0 \mathrm{mg} \mathrm{dm}^{-3}, \mathrm{H}+\mathrm{Al} 15.0 \mathrm{mmol}_{\mathrm{c}} \mathrm{dm}^{-3}, \mathrm{~K} 0.5 \mathrm{mmol}_{\mathrm{C}}$ $\mathrm{dm}^{-3}$, Ca $27.0 \mathrm{mmol}_{\mathrm{c}} \mathrm{dm}^{-3}, \mathrm{Mg} 5.0 \mathrm{mmol}_{\mathrm{c}} \mathrm{dm}^{-3}$, cation exchange capacity $47.5 \mathrm{mmol}_{\mathrm{c}} \mathrm{dm}^{-3}$, and base saturation $68.4 \%$.

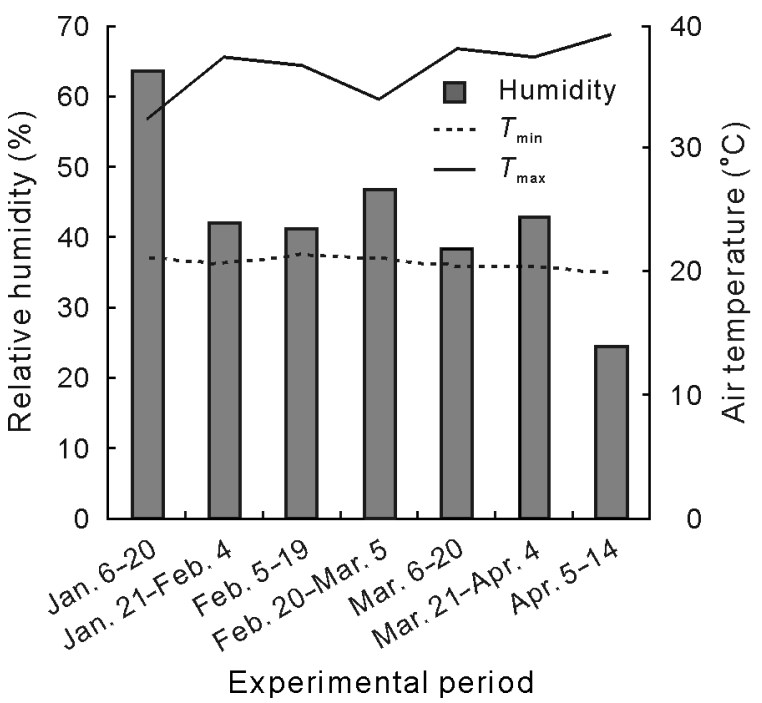

Fig. 1 Minimum and maximum temperatures $\left(T_{\min }\right.$ and $T_{\max }$, respectively) and relative humidity inside the greenhouse during the experimental period.

\section{Experimental design}

The experimental design was completely randomized and consisted of a $2 \times 4$ factorial scheme (two sources and four doses of $\mathrm{Si}$ ) with four replications. The treatments included the application of nanosilica $\left(\mathrm{Si}=106.0 \mathrm{~g} \mathrm{~L}^{-1}\right)$ and soluble silicate $(\mathrm{Si}=115.2 \mathrm{~g}$ $\left.\mathrm{L}^{-1}, \mathrm{Na}_{2} \mathrm{O}=60.5 \mathrm{~g} \mathrm{~L}^{-1}\right)$ to seeding furrows at Si doses of $0,605,1210$, and $2420 \mathrm{~g} \mathrm{ha}^{-1}$. The used nanosilica (Cab-O-Sperse, PG 022) was supplied by Cabot Brasil Industria e Comercio Ltda., São Paulo, Brazil and had a particle surface area of $200 \mathrm{~m}^{2} \mathrm{~g}^{-1}$ with particle size $10 \%<200 \mathrm{~nm}, 70 \%<100 \mathrm{~nm}$, and 20\% 100-199 nm. Seeds were sprayed with treatment solutions so that $\mathrm{Si}$ would be deposited under the seed. This technique simulates seeding furrow spraying in the field. Half the soil was added to a pot, and solutions were sprayed onto the soil. The remaining soil was then added to the pot, and the seeds were sown in furrows of approximately $5 \mathrm{~cm}$ in depth. Treatment solutions were applied using a hand-held sprayer at $200 \mathrm{~L} \mathrm{ha}^{-1}$, considering the surface areas of the pots to ensure uniform product distribution. At the time of application, the temperature was $28.9^{\circ} \mathrm{C}$ and the relative humidity was $62 \%$.

Before sowing and spraying, fertilizers were macerated and set aside for each pot, and then mixed into the entire soil volume before rice planting. The follo- 
wing fertilizer doses were used for $1 \mathrm{dm}^{3}$ of soil: $80 \mathrm{mg}$ N, $200 \mathrm{mg} \mathrm{P,} 150 \mathrm{mg} \mathrm{K,} 10 \mathrm{mg} \mathrm{Zn,} 0.5 \mathrm{mg} \mathrm{B,} 10 \mathrm{mg} \mathrm{Mg}$, and $5 \mathrm{mg} \mathrm{Mn}$, in the forms of urea, superphosphate, potassium chloride, zinc sulfate, boric acid, magnesium sulfate, and manganese sulfate, respectively. Fertilization was carried out according to the recommendations of Malavolta (1981). Nitrogen was applied at the doses of $20 \mathrm{mg} \mathrm{dm}^{-3}$ at sowing, $30 \mathrm{mg} \mathrm{dm}^{-3}$ at the beginning of tillering (20 d after emergence, DAE), and 30 $\mathrm{mg} \mathrm{dm}{ }^{-3}$ at the initiation of panicle primordial (55 DAE). The form and amount of $\mathrm{N}$ used were based on the recommendations of Fageria (2001). Twelve BRSEsmeralda rice seeds were sown per pot. At 10 DAE, each pot was thinned to eight plants. At blooming, each pot was thinned again to two plants. The water content in each pot was adjusted daily based on the weights of control pots.

\section{Determinations of $C, N$, and lignin contents}

At blooming, all flag leaves of six plants were harvested and two plants remained intact until grain harvest in each pot. The flag leaves were washed with distilled water, dried in a forced air circulation oven at 65-70 ${ }^{\circ} \mathrm{C}$ until constant weight, ground, and stored in paper bags in a moisture-free cabinet. The $\mathrm{C}$ and $\mathrm{N}$ contents of the dried leaves were determined using an LECO CN628 elemental analyzer (LECO, USA).

To determine the lignin content, the acid detergent fiber (ADF) was first measured, followed by the "Klason" or acid detergent lignin (Silva and Queiroz, 2002). For the ADF determination, $50 \mathrm{~mL}$ acid detergent solution was added to $0.5 \mathrm{~g}$ sample of dried leaves, and then autoclaved at $1.5 \mathrm{~atm}$ for $40 \mathrm{~min}$. The suspension was washed with $30-40 \mathrm{~mL}$ distilled water at $95-100{ }^{\circ} \mathrm{C}$ and filtered three times. After the third washing, the residue was filtered under vacuum until dry. Residues were oven-dried for $8 \mathrm{~h}$ at $100{ }^{\circ} \mathrm{C}$, cooled in a desiccator, and then weighed (weight 1 ). To determine the lignin content, $30 \mathrm{~mL} 72 \% \mathrm{H}_{2} \mathrm{SO}_{4}\left(15{ }^{\circ} \mathrm{C}\right)$ were added to each filter funnel. The acid and residue were mixed, and the mixture was allowed to cool to $20{ }^{\circ} \mathrm{C}$. One hour later, the filter funnels were replenished, followed by two more washings. After that, the residues were filtered under vacuum until dry, and then the filter funnels and residues were washed in hot water $\left(95-100{ }^{\circ} \mathrm{C}\right)$. Washing was repeated until the acid was completely removed, and the residue was filtered under vacuum until dry once again. The filter funnels and the residues were then dried at $100{ }^{\circ} \mathrm{C}$ for $8 \mathrm{~h}$ or overnight, and reweighed after cooling down in a desiccator (weight 2). Afterward, the filter funnels were placed in a muffle furnace at $500{ }^{\circ} \mathrm{C}$ for 3 $\mathrm{h}$, cooled down in a desiccator, and then reweighed (weight 3). The ADF and lignin contents were determined from the weight losses: $\mathrm{ADF}=$ (weight $2-$ weight 1$)$ /sample weight; lignin $=($ weight $2-$ weight 3$) /$ sample weight.

\section{Scanning electron microscopy (SEM) analysis}

The analysis process followed the protocol routinely used at the Laboratory of Electronic Microscopy of Faculdade de Ciências Agrárias e Veterinárias of UNESP de Jaboticabal in Brazil (Maia and Santos, 1997). Flag leaf blade segments of approximately $1 \mathrm{~cm}$ long were collected at blooming from the treatments with Si dose of $2420 \mathrm{~g} \mathrm{ha}^{-1}$. Leaves were cut into two main parts and fixed with $3 \%$ glutaraldehyde for $48 \mathrm{~h}$. The material was then dehydrated in a series of increasing ethanol concentrations $(30 \%, 50 \%, 70 \%$, $80 \%, 90 \%$, and $100 \%$ ), at 20 min intervals. Leaf samples were then dried in a dryer (EMS-850, Industry Road, USA) until the critical $\mathrm{CO}_{2}$ point was reached. Samples were mounted with the adaxial side up and placed in a Denton Vacuum metallizer (Denton Vacuum, USA) for $120 \mathrm{~min}$. Scanning electron micrographs were then taken at $750 \times$ magnification using a JSM5410 SEM (Hitachi S-570, Japan) (Han et al., 2016).

\section{Determinations of experimental parameters}

The net $\mathrm{C}$ assimilation and transpiration rates were determined at the grain filling stage (milky grain), using two randomly selected flag leaves per plant in each pot. Gas exchange performance is better assessed when the photosynthetic photon flux density is higher and before the temperature increases to a limiting value for C3 photosynthesis (Feistler and Habermann, 2012). Therefore, the plants were evaluated between 9:00 a.m. and 11:00 a.m. using a portable infrared gas analyzer (LI-6400, LI-COR, USA). During the gas exchange measurement period, the temperature ranged from 31.4 to $37.9{ }^{\circ} \mathrm{C}$ and the average relative humidity was $60.1 \%$. The mean photon flux density in the external environment was $503.5 \mu \mathrm{mol} \mathrm{m} \mathrm{m}^{-2} \mathrm{~s}^{-1}$, while that in the chamber was $1500 \mu \mathrm{mol} \mathrm{m} \mathrm{m}^{-2} \mathrm{~s}^{-1}$.

At the grain physiological maturity stage, two plants from each pot were cut at the soil level. Leaves and stems were separated from the panicles. Whole plants, except for the panicles, were dried in a forced air circulation oven at $65^{\circ} \mathrm{C}$ for $72 \mathrm{~h}$ and then weighed to determine the dry matter weight. Afterward, the plant material was milled to determine the contents of N, P (Bataglia et al., 1983), and Si (Korndörfer et al., 2004). The amounts of nutrients accumulated were calculated from the nutrient contents in the plant tissue 
and dry matter. Straw panicles were manually separated from the grain to determine net grain yield, which was corrected for a $130 \mathrm{~g} \mathrm{~kg}^{-1}$ water content.

Soil samples were collected from the top $15 \mathrm{~cm}$ of each pot, where the Si sprays were applied at sowing. The samples were then air-dried and sieved through a 2-mm mesh sieve. The Si content was determined using $0.01 \mathrm{~mol} \mathrm{~L}^{-1} \mathrm{CaCl}_{2}$ (Korndörfer et al., 2004).

\section{Data analysis}

Data were subjected to analysis of variance (ANOVA). The Si treatments were compared using the Tukey's test at $P<0.05$. The effects of Si doses were evaluated by regression analysis, since the magnitudes of regression coefficients were significant at $P<0.05$ as determined by the $F$-test. All statistical analyses were performed by the SISVAR 4.3 (Ferreira, 2008).

\section{RESULTS AND DISCUSSION}

Si in soil and plant and Si accumulation in plant shoot

Nanosilica application increased the Si content in soil to a maximum of $4.31 \mathrm{~g} \mathrm{~kg}^{-1}$ when a $\mathrm{Si}$ dose of $1643 \mathrm{~g} \mathrm{ha}^{-1}$ was used. Soluble silicate applications linearly increased the Si content in soil to a maximum of $3.75 \mathrm{~g} \mathrm{~kg}^{-1}$ at the highest Si dose (Fig. 2).

Regardless of the Si source, the maximum levels of $\mathrm{Si}$ in soil were not high as the products were applied locally and at moderate doses. Soluble silicate significantly increased the Si content in leaf when compared with nanosilica (Fig. 2), with a maximum of $8.49 \mathrm{~g} \mathrm{~kg}^{-1}$ at the Si dose of $1833 \mathrm{~g} \mathrm{ha}^{-1}$ (Fig. 2). Nanosilica linearly increased the $\mathrm{Si}$ content in leaf to a maximum of 7.90 $\mathrm{g} \mathrm{kg}^{-1}$ at the highest dose (Fig. 2), which was lower than that reported by Korndörfer et al. (1999a) $(<17$ $\left.\mathrm{g} \mathrm{kg}^{-1}\right)$. These differences between the Si contents in leaf can be explained by the different rice cultivars and Si doses used in the two studies.

Regardless of the Si source, spray application increased Si accumulation in plant. Soluble silicate increased $\mathrm{Si}$ accumulation in plant to a maximum of $282.93 \mathrm{~g} \mathrm{~kg}^{-1}$ at the Si dose of $1314 \mathrm{~g} \mathrm{ha}^{-1}$. Nanosilica linearly increased $\mathrm{Si}$ accumulation in plant to a maximum of $282.90 \mathrm{~g} \mathrm{~kg}^{-1}$ at the highest Si dose (Fig. 2). The Si content in the soil corroborates these findings.

\section{$N$ and $P$ accumulation}

Nanosilica was the most promising Si source for promoting greater increase in Si accumulation both in the soil and rice shoot when compared with other Si
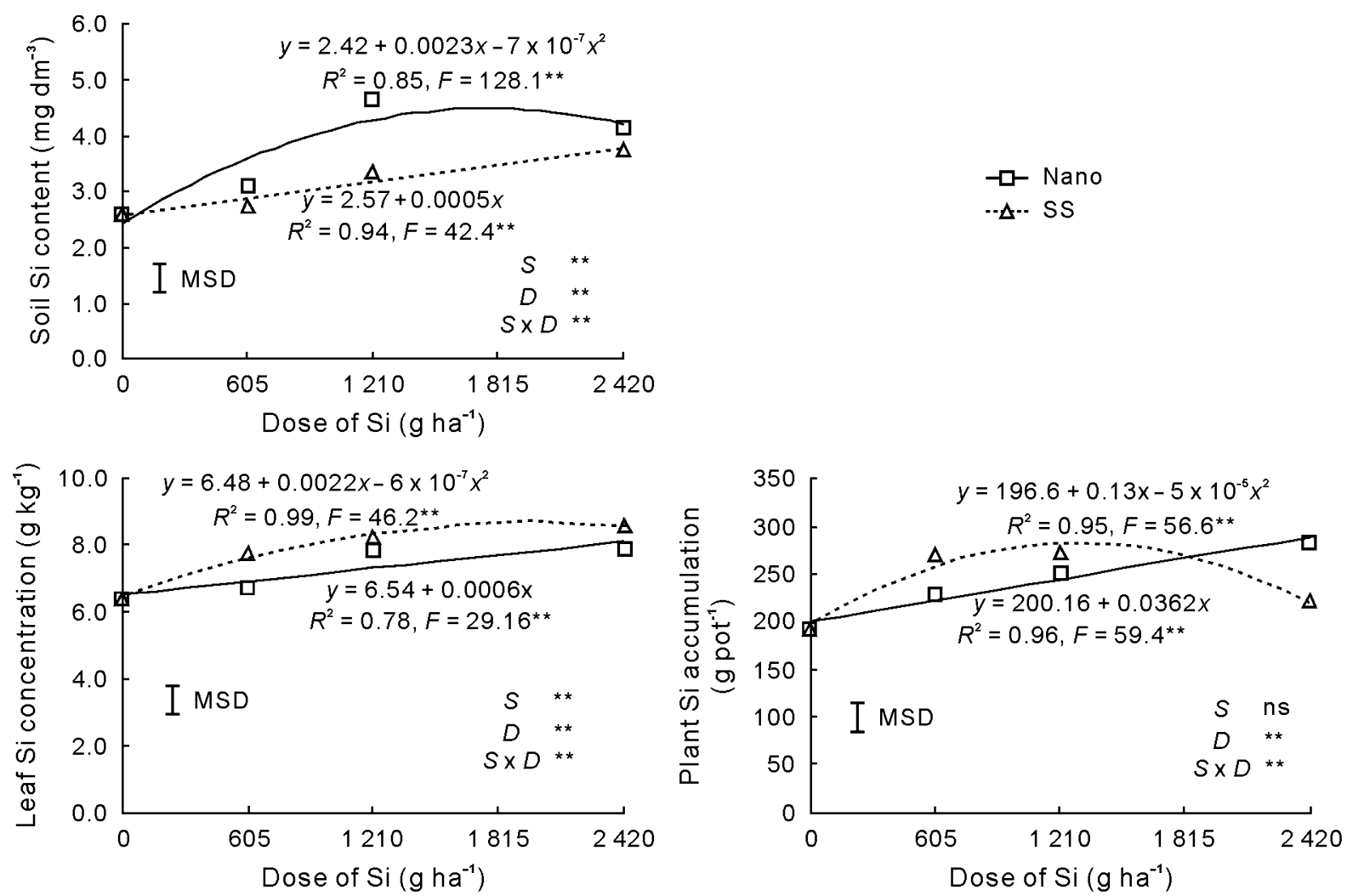

Fig. 2 Silicon ( $\mathrm{Si}$ ) content in soil, Si concentration in rice flag leaf, and Si accumulation in rice plant as functions of Si source $(S)$, nanosilica (Nano) and soluble silicate $(\mathrm{SS})$, and dose $(D)$ applied to the seeding furrows. MSD means the minimum significant difference at $P<0.05$ according to the Tukey's test. The asterisk $(* *)$ indicates significant difference at $P<0.01$. ns $=$ not significant. 
sources. Regardless of the Si source, Si doses did not affect $\mathrm{N}$ and $\mathrm{P}$ accumulation in rice plant (Fig. 3).

The lack of correlation between Si dose and N accumulation in rice plant was reported by Artigiani et al. (2014), and the lack of correlation between Si dose and $\mathrm{P}$ accumulation in rice plant was reported by Alovisi et al. (2007).

\section{$C$ and lignin contents in rice leaf}

The $\mathrm{C}$ content in the leaf blades of rice plants treated with nanosilica was lower than that of plants treated with soluble silicate (Fig. 4). The reduction in $\mathrm{C}$ content at high $\mathrm{Si}$ levels may be due to the partial substitution of $\mathrm{Si}$ for $\mathrm{C}$ in the organic compounds of plant tissues (Schaller et al., 2012). According to Raven (1983), this change is advantageous to plant, since Si compounds are energetically cheaper to form, compared with $\mathrm{C}$ compounds, and provide structural protection such as lignified structures (Schoelynck et

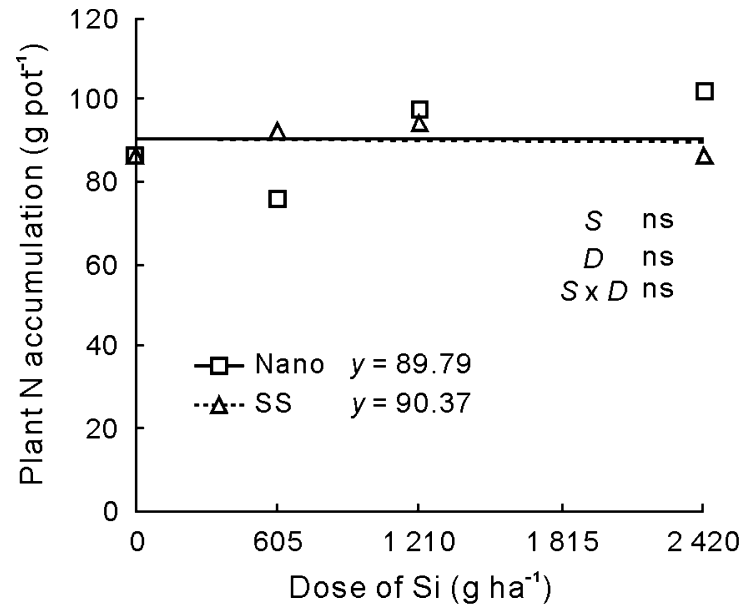

al., 2010). Inanaga et al. (1995) reported that Si was associated with a lignin-carbohydrate complex in rice epidermal leaf cell walls and may increase lignification.

At all doses, nanosilica resulted in higher leaf lignin content than soluble silicate (Fig. 4). At the Si dose of $2420 \mathrm{~g} \mathrm{ha}^{-1}$, nanosilica produced the highest leaf lignin content. Lignin contributes to plant pathogen resistance by reinforcing cell walls (Hatfield and Vermerris, 2001). Studies on rice have reported that Si increases lignin concentration in plant tissues (Rodrigues et al., 2005; Cai et al., 2008; Schurt et al., 2013). Si may associate with the lignin-carbohydrate complex in rice leaf epidermal cell walls and increase the lignification of these structures (Inanaga et al., 1995).

\section{$C: N: P$ stoichiometry in rice shoot}

Determination of the C:N:P stoichiometry as a function of Si application may reveal the correlations between plant Si uptake, $\mathrm{C}$ fixation, and $\mathrm{N}$ and $\mathrm{P}$ ac-

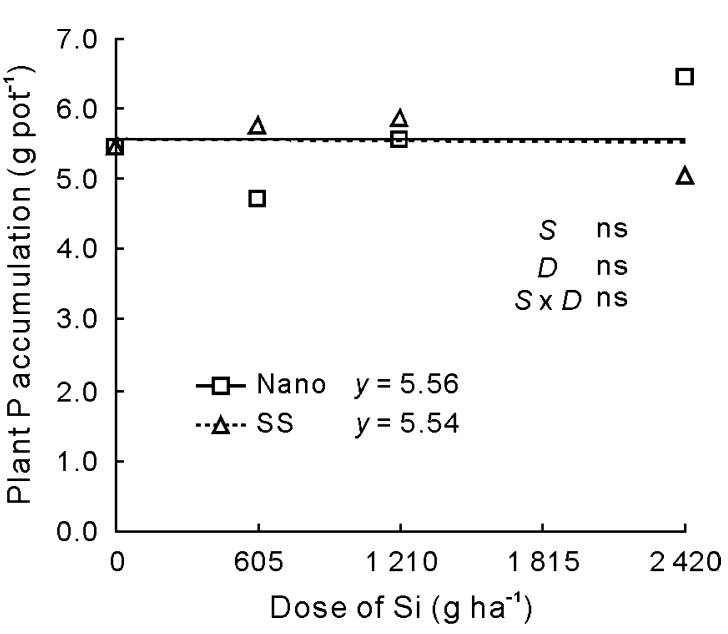

Fig. 3 Accumulation of $\mathrm{N}$ and $\mathrm{P}$ in rice plant as functions of silicon source $(S)$, nanosilica (Nano) and soluble silicate (SS), and dose $(D)$ applied to the seeding furrows. ns = not significant.
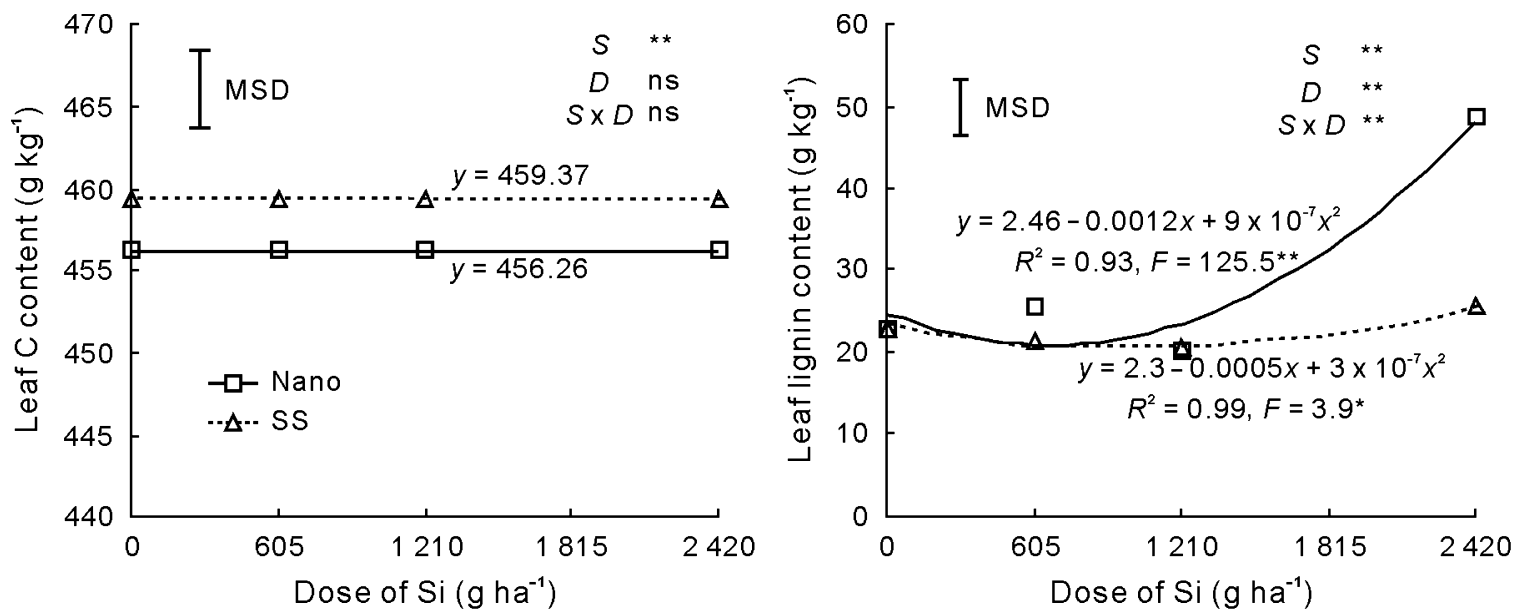

Fig. $4 \mathrm{C}$ and lignin contents in rice leaf as functions of silicon source $(S)$, nanosilica (Nano) and soluble silicate $(\mathrm{SS})$, and dose $(D)$ applied to the seeding furrows. MSD means the minimum significant difference at $P<0.05$ according to the Tukey's test. The asterisk $(* *)$ indicates significant difference at $P<0.01$. ns $=$ not significant. 
cumulation. Silicon forms phytoliths, which are energetically cheaper than the $\mathrm{C}$ compounds derived from enzymatic syntheses (Raven, 1983). In the soil, phytoliths can promote the desorption of $\mathrm{P}$ from retention sites and increase its availability (Alovisi et al., 2007); they can also promote great accumulation of nitrate in the roots (Ávila et al., 2010). Nevertheless, in the present study, soluble silicate at the Si doses of 1210 and $2420 \mathrm{~g} \mathrm{ha}^{-1}$ did not change the C:N:P stoichiometric ratio in the rice shoot (Table I). Eneji et al. (2008) reported strong associations between $\mathrm{Si}, \mathrm{N}$, and $\mathrm{P}$ uptake in a study with several Si sources and four grass species. The authors indicated that mineral uptake varied according to the Si source used.

In an experiment with $P$. australis, Schaller et al. (2012) reported that Si availability might significantly affect $\mathrm{C}: \mathrm{N}: \mathrm{P}$ stoichiometric ratios in different tissues (leaf blades, sheaths, and culms). These findings corroborate those reported for wheat by Neu et al. (2017). In the present work, the C:N:P stoichiometric ratio refers to the mean shoot values excluding the panicle, which is possibly the reason why the Si treatments showed no pronounced effects. In addition, the Si doses (up to $2420 \mathrm{~g} \mathrm{ha}^{-1}$ ) and sources may have influenced the results. Eneji et al. (2008) reported different results according to the Si sources used.

\section{Scanning electron microscopy analysis}

The SEM analysis showed large amounts of amorphous silica in the flag leaf blades of rice plants treated
TABLE I

$\mathrm{C}: \mathrm{N}: \mathrm{P}$ stoichiometry in rice shoot affected by the sources and doses of silicon $(\mathrm{Si})$ applied to the rice seeding furrows

\begin{tabular}{lrr}
\hline Si source & Si dose & C:N:P \\
\hline \multirow{2}{*}{ Nanosilica } & $\mathrm{g} \mathrm{ha}^{-1}$ & \\
& 0 & $188: 15: 1$ \\
& 605 & $191: 16: 1$ \\
& 1210 & $183: 15: 1$ \\
Soluble silicate & 2420 & $197: 16: 1$ \\
& 0 & $188: 15: 1$ \\
& 605 & $183: 15: 1$ \\
& 1210 & $199: 17: 1$ \\
& 2420 & $199: 17: 1$ \\
\hline
\end{tabular}

with soluble silicate and nanosilica at a Si dose of 2420 $\mathrm{g} \mathrm{ha}^{-1}$ (Fig. 5). Amorphous silica densities were similar for both Si sources; however, they still differed significantly from the control (0 g ha $\left.{ }^{-1} \mathrm{Si}\right)$ (Fig. 5). Relatively low amounts were observed for amorphous silica on the leaf surfaces of rice plants in the control. Therefore, little $\mathrm{Si}$ was available to the plants under these conditions (Fig. 2). The amorphous silica observed in this study had the same shape as those found in wheat by Andrade et al. (2012).

The results from this study and that reported by Schaller et al. (2012) for P. australis suggest that rice plants can absorb Si. Mali and Aery (2008) indicated that transpiration promoted mineral transport to the shoot of wheat. Other correlations between Si doses, plant tissue content, and substrate concentration were reported for bamboo (Ding et al., 2008) and several

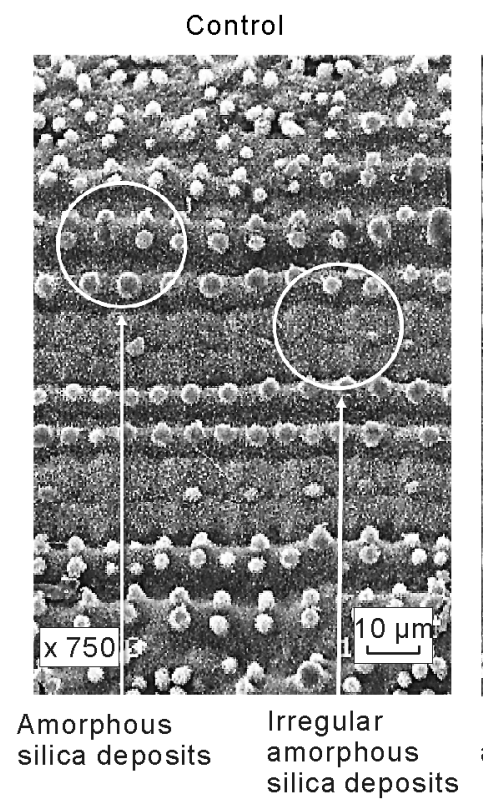

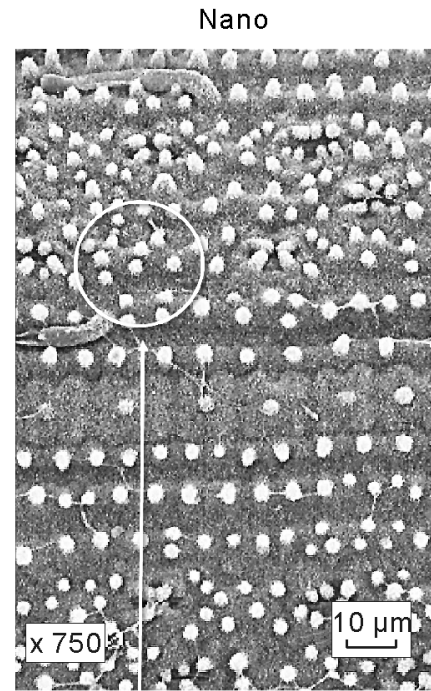

Regular and abundant

amorphous silica deposits

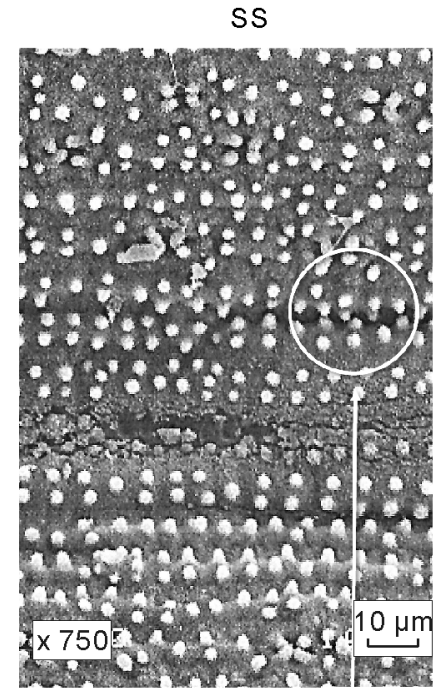

Regular and abundant amorphous silica deposits

Fig. 5 Distributions of amorphous silica in flag leaf (analyzed using scanning electron microscopy) of rice plants treated with 0 g $\mathrm{ha}^{-1}$ silicon (control) and with nanosilica (Nano) and soluble silicate (SS) at a silicon dose of $2420 \mathrm{~g}$ ha ${ }^{-1}$, applied to the seeding furrows. 
crop species (Liang et al., 2006). Schaller et al. (2012) observed that Si uptake and deposition may vary according to the location and may depend on Si availability and transpiration.

The plants passively absorb $\mathrm{Si}$ as monosilicic acid $\left(\mathrm{H}_{4} \mathrm{SiO}_{4}\right)$ together with water (Jones and Handreck, 1967). The movement of $\mathrm{H}_{4} \mathrm{SiO}_{4}$ to the roots depends on its concentration in the soil solution and on the plant species. At low concentrations, the transport by mass flow is reduced. This effect is significant for Siaccumulating plants cultivated in soils with high Si levels (Marschner, 1995). Silicon, in the form of $\mathrm{H}_{4} \mathrm{SiO}_{4}$, is transported in plants via the xylem. Its distribution to other parts of the plant is affected by their transpiration rates and varies according to plant species. The distribution of Si is uniform in plants that accumulate little Si. In the Si-accumulating plants, such as rice, $90 \%$ of the $\mathrm{Si}$ accumulates in the shoot (Korndörfer and Datnoff, 1999). The element is immobile in the plant and is deposited in the leaves, leaf sheaths, stems, bark, and roots. The amount of Si accumulated in the leaf blade is greater than that accumulated in the leaf sheath. Nevertheless, the bark accumulates the most Si content, followed by the leaves and the panicles (Mendes et al., 2011). Silicon confers pathogen resistance to plants by forming a mechanical barrier (Schurt et al., 2013). Silicate fertilization may also increase crop yield.

Net $C$ assimilation rate and transpiration in rice leaf

A significant interaction was observed between the net $\mathrm{C}$ assimilation rate and the transpiration rate in rice leaf (Fig. 6). Soluble silicate application increased the net $\mathrm{C}$ assimilation rate to a maximum of $26.45 \mu \mathrm{mol}$

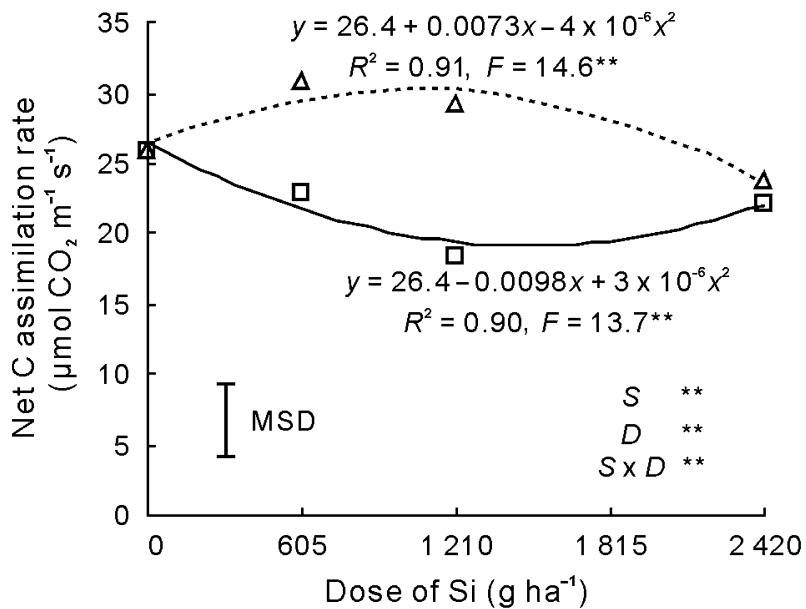

$\mathrm{CO}_{2} \mathrm{~m}^{-1} \mathrm{~s}^{-1}$ at the Si dose of $925 \mathrm{~g} \mathrm{ha}^{-1}$. Nanosilica application decreased the net $\mathrm{C}$ assimilation at the Si doses of 605 and $1210 \mathrm{~g} \mathrm{ha}^{-1}$; however, it slightly increased at higher doses (Fig. 6). Soluble silicate moderately increased the net $\mathrm{C}$ assimilation, which was confirmed by the lack of apparent influence of $\mathrm{Si}$ on $\mathrm{N}$ accumulation in rice plant (Fig. 3). The Si sources used in this study did not affect leaf transpiration rates (Fig. 6). Nanosilica application increased leaf transpiration to a maximum of $23.19 \mathrm{mmol} \mathrm{H}_{2} \mathrm{O} \mathrm{m} \mathrm{m}^{-2} \mathrm{~s}^{-1}$ at the Si dose of $1533 \mathrm{~g} \mathrm{ha}^{-1}$. The maximum leaf transpiration rate obtained with soluble silicate was of 24.27 mmol $\mathrm{H}_{2} \mathrm{O} \mathrm{m} \mathrm{m}^{-2} \mathrm{~s}^{-1}$ at the Si dose of $2075 \mathrm{~g} \mathrm{ha}^{-1}$ (Fig. 6).

Previous studies reported a positive effect of $\mathrm{Si}$ on net $\mathrm{C}$ assimilation and leaf transpiration rates. Rios et al. (2014) observed improvements in $\mathrm{C}$ assimilation and transpiration rates in wheat plants supplied with Si. Moro et al. (2015) stated that the net C assimilation rate in rice increased with $\mathrm{Si}$ supplementation.

\section{Plant dry matter and grain yield}

The shoot dry matter weight of rice was not affected by the Si source (Fig. 7). The same result was reported by Liang et al. (1994), Alovisi et al. (2007), and Ávila et al. (2010). The result, however, contradicts the findings reported by other authors (Deren et al. 1994; Liang, 1994; Korndörfer and Datnoff, 1995; Korndörfer et al., 1999a, b; Gerami and Rameeh, 2012; Moro et al., 2015).

The changes in rice physiology were not significant (Fig. 6), because they did not influence the plant dry matter weight. In addition, grain yield was not significantly influenced by Si source and dose (Fig. 7). These

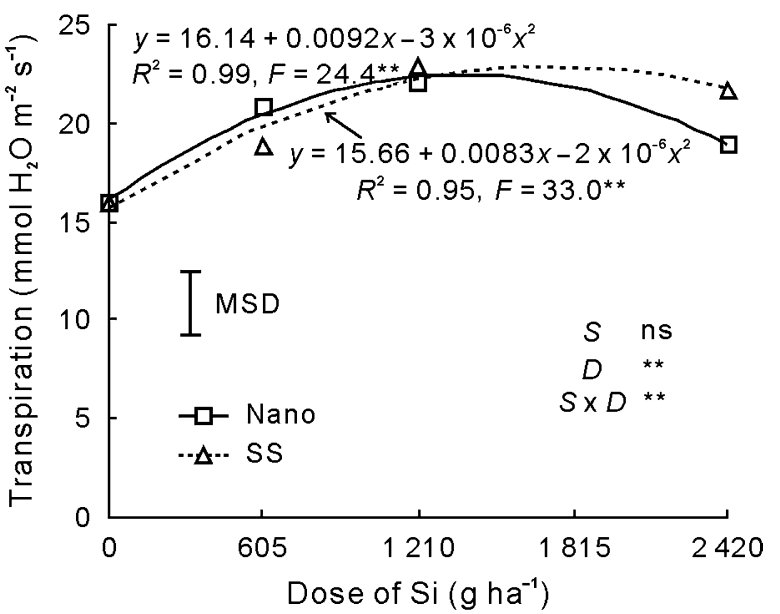

Fig. 6 Net C assimilation and transpiration rates in rice leaf as functions of Si source $(S)$, nanosilica (Nano) and soluble silicate (SS), and dose $(D)$ applied to the seeding furrows. MSD means the minimum significant difference at $P<0.05$ according to the Tukey's test. The asterisk $(* *)$ indicates significant difference at $P<0.01$. ns $=$ not significant. 

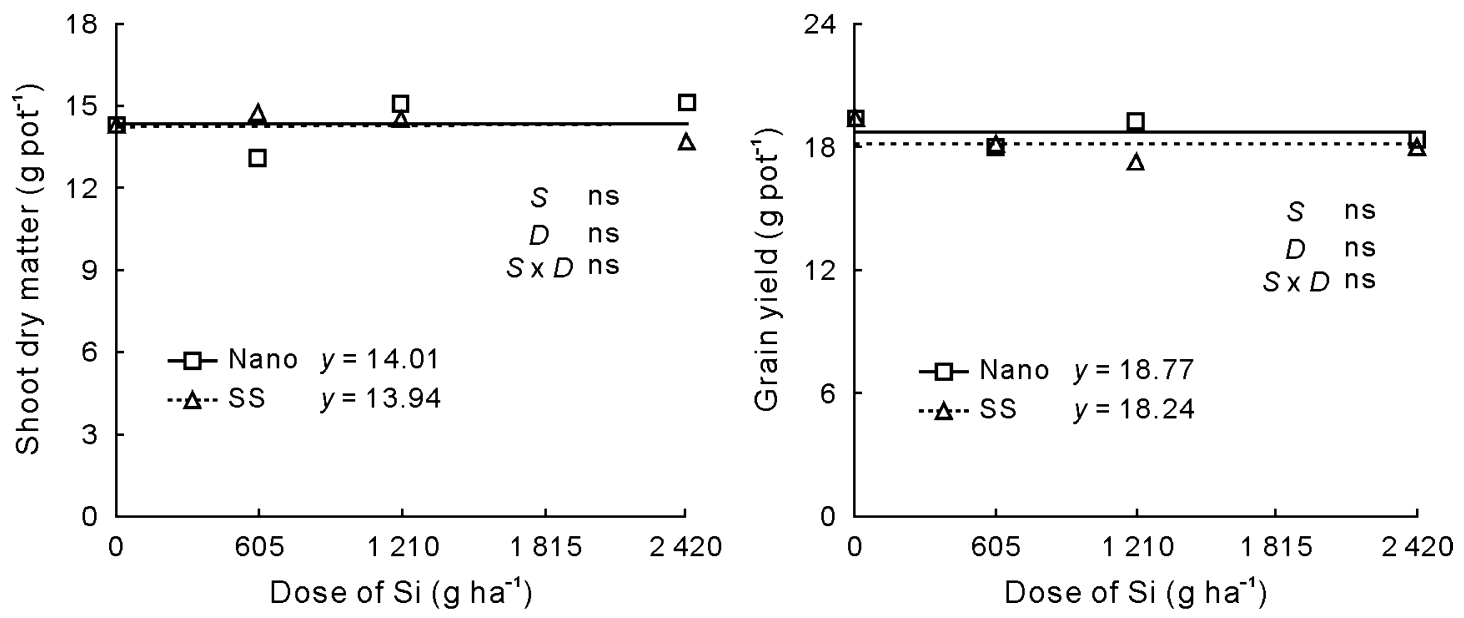

Fig. 7 Shoot dry matter weight and grain yield of rice plants as functions of silicon source $(S)$, nanosilica (Nano) and soluble silicon $(\mathrm{SS})$, and dose $(D)$ applied to the seeding furrows. "ns" means not significant.

results are in accordance with those reported by Ramos et al. (2012) and Artigiani et al. (2014). The fact that Si did not affect rice growth or grain yield may be attributed to the relative lack of biotic or abiotic stress in rice plants during the experiment. The benefits of Si to crops subjected to several stresses, such as drought (Souza et al., 2013; Moro et al., 2015), hypersalinity (Alves et al., 2014), and others, have been widely reported in literature.

\section{CONCLUSIONS}

Little information is available on the physiological and agronomic changes that occur in plants exposed to nanoparticles. This is the first report on the effect of nanosilica applied to the soil on rice plant mineral nutrition in Brazilian agriculture. Silicon application increased $\mathrm{Si}$ accumulation in rice plants, but affected neither the accumulation of $\mathrm{N}$ and $\mathrm{P}$, nor the $\mathrm{C}: \mathrm{N}: \mathrm{P}$ stoichiometry. Nanosilica increased the lignin content in rice leaf. No significant influence was observed on rice plant dry matter weight or grain yield with Si application, owing to the lack of biotic and abiotic stresses. This study provides evidence that rice plants absorb and accumulate Si derived from nanoparticles applied to the soil. Similar studies should be performed to determine the potential of nanoparticles to enhance nutrition in other plant species.

\section{ACKNOWLEDGEMENT}

This experiment, the main author, and the postdoctoral fellowship research were supported by the Coordination for the Improvement of Higher Education Personnel Project of Brazil (No. 129126) and the National Academic Cooperation Program (PROCAD) of
Brazil (Notice 71/2013).

\section{REFERENCES}

Alovisi A M T, Neto A E F, Curi N, Carneiro L F, Alovisi A A. 2007. Silício e fósforo em diferentes solos cultivados com arroz de sequeiro. Acta Sci Agron (in Portuguese). 29: 9-16.

Alves A F, Carvalho K F, De Lima A A, Alves A F, Ferreira T A. 2014. Resposta do silício em condições de estresse salino em feijão caupi variedade Gurgéia. Rev Verde (in Portuguese). 9: 124-128.

Andrade F, Andrade C G, Miglioranza E. 2012. Detecção de sílica em folha bandeira de trigo. Semin Ciênc Agrár (in Portuguese). 33: 2555-2562.

Artigiani A C C A, Crusciol C A C, Nascente A S, Arf O, Alvarez R C F. 2014. Adubação silicatada no sulco e nitrogenada em cobertura no arroz de sequeiro e irrigado por aspersão. Biosci $J$ (in Portuguese). 1: 240-251.

Ávila F W, Baliza D P, Faquin V, Araújo J L, Ramos S J. 2010. Interação entre silício e nitrogênio em arroz cultivado sob solução nutritiva. Rev Ciênc Agron (in Portuguese). 4: $184-190$.

Bataglia O C, Furlani A M C, Teixeira J P F, Furlani P R, Gallo J R. 1983. Métodos de Análise Química de Plantas (in Portuguese). Instituto Agronômico, Campinas.

Cai K Z, Gao D, Luo S M, Zeng R S, Yang J Y, Zhu X Y. 2008. Physiological and cytological mechanisms of siliconinduced resistance in rice against blast disease. Physiol Plant. 134: $324-333$.

Deren C W, Datnoff L E, Snyder G H, Martin F G. 1994. Silicon concentration, disease response, and yield components of rice genotypes grown on flooded organic Histosols. Crop Sci. 34: $733-737$.

Ding T P, Tian S H, Sun L, Wu L H, Zhou J X, Chen Z Y. 2008. Silicon isotope fractionation between rice plants and nutrient solution and its significance to the study of the silicone cycle. Geochim Cosmochim Acta. 72: 5600-5615.

Empresa Brasileira de Pesquisa Agropecuária (Embrapa). 2013. Centro nacional de pesquisa de solos. In De Pesquisa Agropecuária E B (ed.) Sistema Brasileiro de Classificação de Solos (in Portuguese). 3rd Edn. Embrapa Solos, Rio de Janeiro. pp. $75-105$.

Eneji A E, Inanaga S, Muranaka S, Li J, Hattori T, An P, Tsu- 
ji W. 2008. Growth and nutrient use in four grasses under drought stress as mediated by silicon fertilizers. J Plant Nutr. 31: $355-365$.

Epstein E. 2001. Silicon in plants: Facts vs. concepts. In Datnoff L E, Snyder G H, Korndörfer G H (eds.) Silicon in Agriculture. Elsevier, Amsterdam. pp. 1-16.

Fageria N K. 2001. Screening method of lowland rice genotypes for zinc uptake efficiency. Sci Agric. 58: 623-626.

Feistler A M, Habermann G. 2012. Assessing the role of vertical leaves within the photosynthetic function of Styrax camporum under drought conditions. Photosynthetica. 50: 613-622.

Ferreira D F. 2008. SISVAR: Um programa para análises e ensino de estatística. Rev Symposium (in Portuguese). 6: 36-41.

Gerami M, Rameeh V. 2012. Study of silicon and nitrogen effects on yield components and shoot ions nutrient composition in rice. Agriculture. 58: 93-98.

Guimarães C M, Stone L F, Rangel P H N, De Silva A C. 2013. Tolerance of upland rice genotypes to water deficit. Rev Bras Eng Agríc Ambient. 17: 805-810.

Han Y Q, Li P, Gong S L, Yang L, Wen L Z, Hou M L. 2016. Defense responses in rice induced by silicon amendment against infestation by the leaf folder Cnaphalocrocis medinalis. PLoS ONE. 11: e0153918.

Hatfield R, Vermerris W. 2001. Lignin formation in plants. The dilemma of linkage specificity. Plant Physiol. 126: 13511357.

Hegde B A, Pawar R B. 1981. Effect of silicon foliar application on growth, tillering and photosynthetic efficiency in rice varieties Soorya and Suhasini. J Univ Sci Technol. 18: 191-193.

Inanaga S, Okasaka A, Tanaka S. 1995. Does silicon exist in association with organic compounds in rice plant? Soil Sci Plant Nutr. 41: 111-117.

Janmohammadi M, Sabaghnia N. 2015. Effect of pre-sowing seed treatments with silicon nanoparticles on germinability of sunflower (Helianthus annuus). Bot Lith. 21: 13-21.

Jones L H P, Handreck K A. 1967. Silica in soils, plants, and animals. Adv Agron. 19: 107-149.

Korndörfer G H, Arantes V A, Corrêa G F, Corrêa G H. 1999a. Efeito do silicato de cálcio no teor de silício no solo e na produção de grãos de arroz de sequeiro. Rev Bras Ciênc Solo (in Portuguese). 23: 635-641.

Korndörfer G H, Coelho N M, Snyder G H, Mizutani C T. 1999b. Avaliação de métodos de extração de silício em solos cultivados com arroz de sequeiro. Rev Bras Ciênc Solo (in Portuguese). 23: 101-106.

Korndörfer G H, Datnoff L E. 1995. Adubação com silício: Uma alternativa no controle de doenças da cana-de-açúcar e do arroz. Inf Agron (in Portuguese). 70: 1-3.

Korndörfer G H, Pereira H S, Nolla A. 2004. Análise de Silício: Solo, Planta e Fertilizante (in Portuguese). Universidade Federal de Uberlândia, Uberlândia.

Liang Y C, Hua H X, Zhu Y G, Zhang J, Cheng C M, Romheld V. 2006. Importance of plant species and external silicon concentration to active silicon uptake and transport. New Phytol. 172: $63-72$

Liang Y C, Ma T S, Li F J, Feng Y J. 1994. Silicon availability and response of rice and wheat to silicon in calcareous soils. Comm Soil Sci Plant. 25: 2285-2297.

Ma J F, Miyake Y, Takahashi E. 2001. Silicon as a beneficial element for crop plant. In Datnoff L E, Snyder G H, Korndorfer G H (eds.) Silicon in Agriculture. Elsevier Science, New York. pp. 17-39.
Maia A S, Santos J M. 1997. A SEM technique for preparing biological control agents of nematodes in action. Acta Microsc. 6: $550-551$.

Malavolta E. 1981. Manual de Química Agrícola: Adubos e Adubação (in Portuguese). 3rd Edn. Editora Agronômica Ceres, São Paulo.

Mali M, Aery N C. 2008. Influence of silicon on growth, relative water contents and uptake of silicon, calcium and potassium in wheat grown in nutrient solution. J Plant Nutr. 31 $1867-1876$.

Marschner H. 1995. Mineral Nutrition of Higher Plants. Academic Press, New York.

Mendes L S, De Souza C H E, Machado V J. 2011. Adubação com silício: Influência sobre o solo, planta, pragas e patógenos. Rev Cerrado Agrociência (in Portuguese). 2: 51-63.

Mengel K E, Kirkby G A. 1987. Principles of Plant Nutrition. 4th Edn. International Potash Institute (IPI), Bern.

Moro A L, Broetto I, Moro E. 2015. Respostas antioxidativas, fisiológicas e produtiva de arroz cultivado sob deficiência hídrica e adubação silicatada. Semin Ciênc Agrár (in Portuguese). 36: 3013-3028.

Nair R, Varghese S H, Nair B G, Maekawa T, Yoshida Y, Kumar D S. 2010. Nanoparticulate material delivery to plants. Plant Sci. 179: 154-163.

Neu S, Schaller J, Dudel E G. 2017. Silicon availability modifies nutrient use efficiency and content, C:N:P stoichiometry, and productivity of winter wheat (Triticum aestivum L.). Sci Rep. 7: 40829.

Pawar R B, Hegde B A. 1978. Effect of silicon foliar application on growth, tillering and photosynthetic efficiency in Oryza sativa var. Satya. Ind J Plant Physiol. 21: 12-16.

Prado R M, Fernandes F M, Natale W. 2001. Uso agríCola da Escória de Siderurgia no Brasil: Estudos na Cultura da Canade-Açúcar (in Portuguese). FUNEP, Jaboticabal.

Ramos D T, Da Luz P B, Machado M D, Cassiolato M E, Sobrinho S P, Neves L G. 2012. Influência da adubação silicatada na produção de arroz de sequeiro. Rev Bras Ciênc Agrár (in Portuguese). 7: 543-547.

Raven J A. 1983. The transport and function of silicon in plants. Biol Rev. 58: 179-207.

Rios J A, De Ávila Rodrigues F, Debona D, Silva L C. 2014 Photosynthetic gas exchange in leaves of wheat plants supplied with silicon and infected with Pyricularia oryzae. Acta Physiol Plant. 36: 371-379.

Rodrigues F A, Jurick W M, Datnoff L E, Jones J B, Rollins J A. 2005. Silicon influences cytological and molecular events in compatible and incompatible rice-Magnaporthe grisea interactions. Physiol Mol Plant Pathol. 66: 144-159.

Schaller J, Brackhage C, Gessner M O, Bäuker E, Gert Dudel E. 2012. Silicon supply modifies C:N:P stoichiometry and growth of Phragmites australis. Plant Biol. 14: 392-396.

Schoelynck J, Bal K, Backx H, Okruszko T, Meire P, Struyf E. 2010. Silica uptake in aquatic and wetland macrophytes: A strategic choice between silica, lignin and cellulose. New Phytol. 186: 385-391.

Schurt D A, Rodrigues F A, Colodette J L, Carré-Missio V. 2013. Efeito do silício nas concentrações de lignina e de açúcares em bainhas de folhas de arroz infectadas por Rhizoctonia solani. Bragantia (in Portuguese). 72: 360-366.

Silva D, Queiroz A D. 2002. Análise de Alimentos: Métodos Químicos e Biológicos (in Portuguese). 3rd Edn. Universidade Federal de Viçosa, Viçosa.

Souza L C, Siqueira J A M, Silva J L S, Coelho C C R, Neves M G, Oliveira Neto C F. 2013. Osmorreguladores em plantas de 
sorgo sob suspensão hídrica e diferentes níveis de silício. Rev Bras Milho E Sorgo (in Portuguese). 12: 240-249.

Tripathi D K, Singh V P, Prasad S M, Chauhan D K, Dubey N K. 2015. Silicon nanoparticles ( $\mathrm{SiNp}$ ) alleviate chromium (VI) phytotoxicity in Pisum sativum (L.) seedlings. Plant
Physiol Biochem. 96: 189-198.

Van Raij B, Andrade J C, Cantarella H, Quaggio J A. 2001. Análise Química Para Avaliação da Fertilidade de Solos Tropicais (in Portuguese). Instituto Agronômico, Campinas. 